\title{
The Big Society: Ten Years On
}

On $10^{\text {th }}$ November 2009, David Cameron launched a determined pitch to depict a distinctive and coherent future vision of society that would form the bedrock of an incoming Conservative government's social policy agenda. Speaking at the Hugo Young Memorial Lecture in London, he announced an aspiration to create 'The Big Society', and he pledged that it would revive a more dynamic Conservative social policy agenda, refresh the party's approach towards the role of the state, while ostensibly rehabilitating the wider public image of Conservatism in the process. In retrospect, some have viewed this as a landmark speech of his leadership, which offered the prospect of a markedly new and potentially bolder direction for the Conservative Party. Yet this specific agenda would later stutter and arguably come to symbolise what many of Cameron's critics claimed was symptomatic of his premiership; namely that it offered a willingness to engage with new ideas and innovative rhetoric, yet which ultimately proved superficial and lacking in terms of practical delivery and substance. Ten years on, it is time to assess the overall legacy of this particular policy agenda, and what if anything it achieved in the subsequent decade.

\section{Origins of The Big Society}

This initial 'Big Society' speech formed part of Cameron's sustained, longer-term strategy of seeking to change and 'modernise' his party's image, following his accession to the Conservative leadership at the end of 2005. A central part of this approach was to cultivate a more positive public perception of the Conservatives in the early $21^{\text {st }}$ century, with the ultimate aim of achieving electoral success. Branded as the 'nasty party' by then party chairman Theresa May back in $2002^{1}$, Cameron and his fellow modernisers were fully aware of the Conservatives' often toxic image problems, and they prioritised the need to instil a more compassionate and paternalistic tone if more positive electoral outcomes were to be fulfilled. In this sense, there was a willingness to re-engage with the party's Disraelian 'One Nation' legacy and its more harmonious and unifying message, with a more social as opposed to economic focus; and such sentiments have been repeated in Cameron's recent autobiography 'For The Record'. This was a particular priority within the context of the party flatlining support during three successive general election defeats (1997-2005) ${ }^{2}$, and it was 
evidently apparent that a much broader coalition of popular support would be needed if the party was going to return to government in the foreseeable future. Cameron was particularly keen to transcend the Thatcherite individualistic legacy of 'survival of the fittest', which as a form of neoliberal populism delivered three Conservative general election victories between 1979 and 1987; but as a longer term legacy had instilled worsening social divisions and disharmony, while significantly widening the gap between rich and poor. By the time Cameron became leader party fifteen years after Thatcher's departure, this negative aura continued to be an 'albatross' hung around the party's neck.

In seeking some specific theoretical influence to bolster this modernising and forwardlooking approach, Cameron's inner-circle delved back into history, specifically the $18^{\text {th }}$ century ideas of Edmund Burke, who idealised dynamic 'little platoons' of individuals interacting positively on a social level. Burke's ideas about greater civic and mutualised responsibilities for 'atomized' citizens have consequently been cited as being prominent in shaping this new social policy theme ${ }^{3}$, with such socialized interactions existing within an historical era when the state's role was far less interventionist than its $21^{\text {st }}$ century variant. In therefore seeking to cultivate a revamped social policy agenda and refined political identity for his party, Cameron had indicated a willingness to widen his pool of theoretical influences, which pointed to a different and broadly more pro-active role for the state's functions compared to the most recent Conservative governments during the 1980 s and 90 s. He even tolerated some alignment with New Labour, with elements of the press calling him the "heir to Blair", which he did not necessarily object to. He utilised the Labourite language of 'social justice', and also rebuked Thatcher's infamous and often misquoted assertion that "there is no such thing as society" , when he declared in his leader's acceptance speech of December 2005 that "There is such a thing as society, it's just not the same thing as the state ${ }^{\prime 5}$. Cameron was also interested in the ideas stemming from the Centre for Social Justice, a right of centre thinktank that advocated a more socially-themed policy agenda to tackle long-term poverty, and which had been founded by former party leader lain Duncan Smith in 2004, while David Willetts' concept of 'Civic Conservatism' from the 1990s was another contemporary influence.

\section{The Big Society's aspirations}


After initially focusing on the political fall-out of the 2007/8 economic crash, Cameron turned his attention to social matters. In doing so he argued in a distinctly non-ideological manner that the past dogmas of both right and left had resulted in recurring failures regarding the role of the state and its social impact within post-war British politics. Cameron and his key advisors such as Steve Hilton ${ }^{6}$ claimed that the neoliberal ideological experiment of the 1980s had resulted in an often distant, inflexible and detached state model that was either unable or unwilling to intervene to address emerging social issues when needed, while the centralised 'big state' of the New Labour era had often suffocated personal initiative and civic freedoms that prevented a dynamic civil society from flourishing. Consequently, Cameron's challenge was to maximise a positive social impact from the state's revised role, declaring in 2009 that "our alternative to big government is the big society" , which signified his pragmatic willingness to reject past approaches. Although initially viewed by cynics as something of a vacuous term utilised to win votes, Cameron's alternative 'Big Society' viewpoint envisaged a 'reimagined state' that would be streamlined in size and scope, and in turn more efficient and less bureaucratic ${ }^{8}$. The state would ultimately be the catalyst for creating the appropriate conditions for instigating social activity, yet its role would be relatively less controlling, and be focused primarily on co-ordinating enhanced levels of 'social capital' ${ }^{9}$ - a concept that entailed citizens socially interacting and positively co-operating, while in the process sharing mutual values and reciprocating experiences. One of the early testing grounds for the Big Society in practice were 'Social Action Projects', whereby prior to the 2010 general election, Conservative campaigners and sometimes parliamentary candidates would instigate grassroots activities within local communities, often involving environmental improvements or regeneration.

This focus on enhanced social engagement, a revised state model and a revitalised civil society were all notable features of this new approach, and Cameron emphasised that substantial public involvement was vital for this programme to work, particularly within the context of historically low and struggling voter participation levels, with electoral turnout for general elections in 2001 and 2005 having been 59\% and 61\% respectively. In launching this agenda he declared: 
'The big society also needs the engagement of that significant percentage of the population who have no record of getting involved - or a desire to do so..... (it) demands mass engagement: a broad culture of responsibility, mutuality and obligation ${ }^{\prime 10}$.

From this evident desire to improve the culture of participation within British society, it was subsequently envisaged that this idealised 'Big Society' approach would eventually have the capacity to reduce the state's role at a future (if undefined) moment in order to devolve power, policy-making and socialized activity downwards to more localised bodies. This process would then supposedly allow individuals to express themselves with a renewed dynamism, within a less centralized yet more communitarian environment, and with a reduced cost of running key public services. Its ultimate goal therefore appeared to be a proactive yet less intrusive state, generating a more efficient and productive government and citizenship, fused together by mutual responsibilities, and ultimately allowing for the emergence of a connected society organised horizontally, not vertically. This vision was outlined in Cameron's initial speech as desiring 'a new role for the state: actively helping to create the big society; directly agitating for, catalysing and galvanising social renewal". ${ }^{11}$

This refreshed attitude towards the state and society was therefore determinedly pursued by Cameron's leadership while in opposition, amidst an ongoing perception among various key sections of the electorate that the Conservatives had a weak record on social policy and in tackling deep-rooted socio-economic issues such as poverty, and even a degree of hostility to public services. This again could be seen as a negative hangover from the Thatcher years, yet by the start of 2010 and with an impending general election in the pipeline, the role of the state and key public services were poised to play a central role. Cameron was keen to engage this problem and address such perceived hostility, and he subsequently pitched his political programme firmly into traditional Labour territory, with a distinct focus on socially-fused concepts such as social mobility, social justice and social capital.

\section{The Big Society in action (2010-15)}

Despite its high-profile intrusion into Cameron's pre-election policy narrative, the 'Big Society' was a relatively minor issue during the 2010 general election campaign itself. Indeed, some 
Conservative candidates complained that when it was brought up on the doorstep it actually caused confusion and failed to inspire voters. Such complex abstractions were arguably inconsistent with more simplistic traditional approaches of 'One Nation' Conservatism, with its focus on pragmatic affinity with the public mood and popular instincts. In a far from convincing general election outcome, Cameron secured power with the Liberal Democrats in coalition, but the indecisive result represented an ongoing failure of the Conservatives to convince sufficient numbers of voters to put their faith in them on such core social policy issues. Yet from another perspective, Cameron's more social emphasis may well have pushed the Conservatives over the line and back into power after thirteen long years in opposition. However once in office, social matters were initially sidelined as economics and the mounting national deficit was prioritised, and as the controversial austerity agenda began to impact, there were adverse social and welfare implications.

While austerity became a driving narrative behind the coalition government's policymaking in subsequent years, critics on the left claimed that the 'Big Society' was merely a byword for cutbacks, with tank-tanks such as Civil Exchange arguing that this flagship social policy had been 'undermined by cuts and distrust' ${ }^{12}$. Cameron repeatedly denied this allegation $^{13,}$, yet it became a recurring criticism that even one-time supporters of his agenda highlighted ${ }^{14}$, with 'Red Tory' reformist figures such as Philip Blond frustrated by the socioeconomic limitations imposed by austerity. In Blond's view, initial public funding was vital for the Big Society agenda to work, and the sustained austerity programme consequently hampered its initially original ethos of a 'pro-poor' agenda ${ }^{15}$ from a right-of-centre perspective, which aspired to improve the prospects of poorer communities. Yet despite such critical commentary, Cameron sought to further widen the scope of his flagship social agenda with ambitious projects such as the 'Big Society Capital' in early 2012, which as a new model of 'social banking' aimed to provide combined public/private funding to boost social enterprises and small community-based businesses. With an initial fund of $f 600$ million $^{16}$, it was a fundamental part of the Cameron government's aim of reshaping how the state functioned in $21^{\text {st }}$ century society, yet its longer-term effectiveness in both political and social terms has been questionable. A similar area of practical concern was that charities, viewed by Cameron as key players within the Big Society model (to bolster public funding), 
complained that donations were reduced after 2010, meaning that grassroots projects often struggled to get off the ground.

Various critics of The Big Society have collectively concluded that financial support was insufficient for its various ambitious schemes to function properly in the longer term, and this re-enforces the key critique that it was incompatible to be pursued alongside deficit reduction and austerity. On this premise, the longer the coalition government continued, and the more it became embroiled in other significant issues such as Europe, party management and balancing the books, the less prominent this specific social agenda became. Controversial welfare reforms such as 'the bedroom tax' and Universal Credit caused social dislocation and worsening living conditions for many, and consequently created less, not more, social harmony. This re-enforced critical claims that talk of a 'Big Society' in 2009-10 had been a cosmetic gimmick, and by the $\mathbf{2 0 1 5}$ general election it had fizzled away to barely register a campaigning murmur.

\section{Theresa May and 'The Shared Society'}

As a member of his Cabinet between 2010-16, Theresa May never appeared to give much explicit credence to Cameron's model of 'The Big Society', yet after becoming Prime Minister in 2016 she arguably stole some of its language and political clothing. While May's advisors were primarily keen to distance her premiership from her immediate predecessor, with her senior advisors Nick Timothy and Fiona Hill believing that Cameron's political approach had been shallow and gimmicky, May was eager to burnish her own compassionate social credentials on a domestic political level. Like Cameron she had long been identified as one of the Conservative Party's key modernizers, and in early 2017 she sought to stamp her own distinct imprint on the social policy debate, launching a similarly sounding 'Shared Society' vision. In this speech she vowed to tackle some "some of the burning injustices that undermine the solidarity of our society ${ }^{\prime 17}$, which by default implied that Cameron and other former Prime Ministers had failed to address such matters. The use of words such as 'solidarity' had more left-wing and communitarian associations, and again seemed to go against the Thatcherite individualistic heritage that had prevailed under Conservative administrations of the 1980s and 90s. 
The specific 'injustices' highlighted by May were the treatment of ethnic minorities in the criminal justice system, the reduced chances of white working-class boys attending university, and support for those with mental health conditions. She also spoke about improving stagnant levels of social mobility. Yet political opponents highlighted that such social trends had been adversely affected by the austerity programme since 2010, but May indicated a desire to eventually move away from economic cutbacks, offering the prospect of a more substantial and interventionist role for the state compared to Cameron. May's inclination to tackle such social problems with improved levels of public spending was hastened by the setback of the 2017 general election, where austerity and its impact was said to have negatively impacted on Conservative Party fortunes ${ }^{18}$. It should be stressed however that even after this electoral blow, financial caution remained in place for May's administration, with genuine social policy innovation suppressed by the crisis-ridden nature of the Brexit saga during her final months in power.

\section{Overview and legacy}

The fundamental critique of the Big Society programme was that for all of its attempts to reinvigorate Conservative social policy intentions, its aspirations were ultimately stunted by the spectre of austerity. It began with a speech that symbolised modernization and reform in the early $21^{\text {st }}$ century, and evolved into a series of policy initiatives in ensuing years, not all of which appeared coherent and applicable in practical terms. Rejecting past ideological approaches of both left and right, it pragmatically sought a revamped model of the state's role regarding its core activity and functions. While Cameron had hoped its narrative would be the ultimate driving force and legacy of his 'modernizing' government, major events such as Brexit transcended this aspiration, while Theresa May similarly struggled to sell her own social vision in the face of ongoing political crisis. The Big Society agenda has therefore been consequently dismissed as an ambitious if often vacuous attempt to rebrand the Conservative Party's image and specific social policy offer, and while it stimulated some interesting debates and ideas, it ultimately failed to deliver in the longer term. It arguably assisted Cameron in achieving power (albeit unconvincingly) at the 2010 general election, but in subsequent years he was unable to practically deliver on its bold original aspirations, particularly so while his 
government simultaneously sought to drive down the national deficit. Whether it was little more than a marketing ploy and whether it would have made more impact in more stable economic times remains a matter of debate.

\footnotetext{
${ }^{1}$ Full text: Theresa May's conference speech, The Guardian, 7th October 2002, https://www.theguardian.com/politics/2002/oct/07/conservatives2002.conservatives1

${ }^{2}$ Between 1997-2005, Conservative general election support had ranged between 30.7-32.4\%.

${ }^{3}$ See Jesse Norman, The Big Society: The Anatomy of the New Politics, (2010) and Edmund Burke, Reflections on the Revolution in France, (1790).

${ }^{4}$ Margaret Thatcher, Interview for Woman's Own (23rd September 1987), https://www.margaretthatcher.org/document/106689

${ }^{5}$ In full: Cameron victory speech, BBC News, 6th December 2005, http://news.bbc.co.uk/1/hi/uk politics/4504722.stm

${ }^{6}$ Matt Chorley, Genius or clueless? The jury is out on the architect of the Big Society, The Independent on Sunday, $22^{\text {nd }}$ May 2011,

https://www.independent.co.uk/news/uk/politics/genius-or-clueless-the-jury-is-out-on-the-architect-of-thebig-society-2287451.html

${ }^{7}$ David Cameron: The Big Society speech, Hugo Young Memorial Lecture, 10th November 2009, https://conservative-speeches.sayit.mysociety.org/speech/601246

${ }^{8}$ B. Williams, The Big Society: Post-Bureaucratic Social Policy in the Twenty-first Century?, The Political Quarterly, (2012).

https://onlinelibrary.wiley.com/doi/full/10.1111/i.1467-923X.2011.02331.x

${ }^{9}$ Emanuele Ferragina and Alessandro Arrigoni., From the Third Way to the Big Society: the rise and fall of social capital, (LSE Blogs: British Politics and Policy, May 26 $\left.{ }^{\text {th }}, 2016\right)$

https://blogs.Ise.ac.uk/politicsandpolicy/big-society-social-capital/

${ }^{10}$ David Cameron: The Big Society speech, Hugo Young Memorial Lecture, 10th November 2009, https://conservative-speeches.sayit.mysociety.org/speech/601246

${ }^{11}$ David Cameron: The Big Society speech, Hugo Young Memorial Lecture, 10th November 2009, https://conservative-speeches.sayit.mysociety.org/speech/601246

${ }^{12}$ Patrick Butler, 'Cameron's 'big society' undermined by cuts and distrust, says study', The Guardian, $7^{\text {th }}$ May 2012,

http://www.guardian.co.uk/society/2012/may/07/david-cameron-big-society-cuts-distrust

${ }^{13}$ Nicholas Watt, David Cameron reveals 'big society' vision - and denies it is just cost cutting, The Guardian, 19th July 2010,

https://www.theguardian.com/politics/2010/jul/19/david-cameron-big-society-launch

${ }^{14}$ See Ben Williams, The Evolution of Conservative Party Social Policy, (2015), p.182

${ }^{15}$ See Philip Blond, Red Tory: How Left and Right Have Broken Britain and How We Can Fix it, (2010).

${ }^{16}$ BBC News, Big Society fund launches with $1600 m$ to invest, (4th April 2012),

https://www.bbc.co.uk/news/business-17602323

17 The shared society, Theresa May speech, 8th January 2017,

https://www.gov.uk/government/speeches/the-shared-society-article-by-theresa-may

18 BBC News, Theresa May's chief of staff Gavin Barwell: Austerity and Brexit cost us, 12th June 2017, https://www.bbc.co.uk/news/election-2017-40251997
} 